\title{
Caracterização Morfoanatômica, Contagem Cromossômica e Viabilidade Polínica de Biótipos de Azevém Suscetível e Resistentes aO HeRBicida GlyphOSATE ${ }^{1}$
}

\author{
Morphoanatomical Characterization, Chromosome Count and Pollen Viability of Glyphosate- \\ Susceptible and Glyphosate-Resistant Italian Ryegrass \\ RUCHEL, Q. ${ }^{2}$, VARGAS, L. ${ }^{3}$, AGOSTINETTO, D. ${ }^{2}$, FERNANDO, J.A. ${ }^{2}$, LÜDTKE, R. ${ }^{2}$ e \\ BOBROWSKI, V.L. ${ }^{2}$
}

\begin{abstract}
RESUMO - O azevém é uma planta daninha de ciclo anual, encontrada em praticamente todas as lavouras de inverno, em pomares e vinhedos da região Sul do Brasil. A espécie é normalmente controlada pelo herbicida glyphosate, no entanto, o uso continuado desse produto selecionou biótipos resistentes. Diferenças na suscetibilidade do azevém a herbicidas têm sido atribuídas a características morfológicas, anatômicas e genéticas das plantas. Os objetivos deste trabalho foram realizar a caracterização morfoanatômica, adequar metodologia para a análise citológica de cromossomos e indicar corantes para testes de viabilidade polínica de biótipos de azevém suscetivel e resistentes ao herbicida glyphosate. As sementes dos biótipos de azevém suspeitos de resistência provieram do município de São Valentin, RS (SVA 1 e SVA 4), e Passo Fundo, RS (PFU 5), e as do biótipo conhecidamente suscetivel (SVA 2), de São Valentin. Os biótipos de azevém estudados que apresentam resistência ao herbicida glyphosate não podem ser diferenciados do biótipo suscetivel através de aspectos morfológicos, não existindo diferenças anatômicas de folha e raiz que evidenciem possibilidade da absorção diferencial do herbicida glyphosate entre os biótipos de azevém. A metodologia para a análise citológica dos biótipos de azevém merece adequações para melhor nitidez dos cromossomos, podendo-se aumentar o tempo de hidrólise e de exposição ao agente antimitótico utilizado neste trabalho, bem como testar outros agentes. Todos os corantes apresentaram bom desempenho na determinação da viabilidade polínica frente aos biótipos avaliados, exceto o azul de tripan, que subestimou os resultados.
\end{abstract}

Palavras-chave: anatomia, cromossomos, Lolium multiflorum, morfologia, Poaceae.

\begin{abstract}
Ryegrass is an annual weed found in all winter crops, orchards and vineyards of southern Brazil. The species is typically controlled by glyphosate. However, continued use of this product has selected resistant biotypes. Differences in herbicide susceptibility of ryegrass have been attributed to differences in morphology, anatomy and genetics of the plants. The objectives of this study was to conduct a morphological and anatomic characterization, adapt the methodology for cytological analysis of chromosomes and select dyes for pollen viability tests with glyphosatesusceptible and resistant ryegrass biotypes. The seeds of ryegrass biotypes with suspected resistance came from the town of São Valentim, RS (SVA 1 and SVA 4) and Passo Fundo, RS (PFU 5) and seeds of the susceptible biotype (SVA 2) were from São Valentim. The ryegrass biotypes with resistance to glyphosate cannot be distinguished from the susceptible biotype by morphological aspects and there are no anatomical differences in leaf and root that allow differential absorption of glyphosate among ryegrass biotypes. The methodology for the cytological analysis of ryegrass biotypes should be adapted for better clarity of chromosomes, allowing an increase in hydrolysis time and exposure to the antimitotic agent used in this study; moreover, other dyes can be tested. All dyes showed good performance in determining pollen viability against the assessed biotypes except for trypan blue, which had poorer results.
\end{abstract}

Keywords: anatomy, chromosomes, Lolium multiflorum, morphology, Poaceae.

Recebido para publicação em 19.3.2015 e aprovado em 5.5.2015.

2 Universidade Federal de Pelotas (UFPel), Pelotas-RS, Brasil, <queli.ruchel@yahoo.com.br>; ${ }^{2}$ Embrapa Trigo, Passo Fundo-RS, Brasil. 


\section{INTRODUÇÃO}

O azevém (Lolium multiflorum) é uma monocotiledônea anual, alógama, adaptada a diversos tipos de solo e altamente produtiva em solos férteis. Essa espécie é de fácil dispersão e está presente e se caracteriza como importante planta daninha em culturas como trigo, soja e pomares na região Sul do Brasil.

O controle do azevém é realizado, quase na sua totalidade, com a aplicação de herbicidas não seletivos, em diferentes estádios fenológicos, sendo o glyphosate o mais utilizado para esse fim. Com o aumento da utilização desse herbicida, os produtores verificaram maior dificuldade no controle do azevém, levando à seleção de biótipos resistentes.

As diferenças na suscetibilidade de espécies de plantas daninhas a herbicidas são atribuídas ao estádio de desenvolvimento da planta, a diferenças na morfologia (área e forma do limbo e ângulos das folhas em relação ao jato de pulverização), à anatomia foliar (presença de estômatos e tricomas, espessura e composição da camada cuticular) e a diferenças na absorção, translocação, compartimentalização e metabolização da molécula herbicida (Dall'Armellina \& Zimdahl, 1989; Westwood et al., 1997; Vargas et al., 1999; Tuffi Santos et al., 2004).

Características morfológicas das folhas influenciam na quantidade de herbicida interceptado e retido; contudo, são características anatômicas que praticamente determinam a facilidade com que esses produtos serão absorvidos. Populações de Brassica juncea tolerantes ao glyphosate apresentaram maior espessura da folha e da cutícula adaxial e maior densidade de tricomas na epiderme superior, bem como menor número de feixes vasculares, em comparação com as plantas suscetíveis, sugerindo que essas diferenças contribuem para a tolerância ao herbicida (Huangfu et al., 2009).

O aparecimento de biótipos resistentes é influenciado também pela variabilidade genética entre plantas, fato que determina a capacidade de resposta à seleção natural e às pressões impostas em função de técnicas de manejo utilizadas. Dessa forma, além da utilização repetitiva do mesmo herbicida ou de herbicidas com o mesmo mecanismo de ação, outros fatores podem estar associados com a evolução da resistência de plantas daninhas, como adaptação, herança, nível de ploidia, fluxo gênico e frequência gênica (Maxwell \& Mortimer, 1994).

A manifestação do genótipo do indivíduo é o resultado da contribuição dos gametas masculino e feminino; quanto maior a viabilidade polínica, maior a possibilidade da formação de diferentes combinações entre alelos, aumentando a variabilidade genética (Souza et al., 2002). A herança da resistência ao glyphosate em azevém é do tipo nuclear, com disseminação rápida na população, via pólen (Vargas et al., 2007). Poáceas de polinização cruzada, como o azevém, têm elevado potencial para transmitir seus genes às plantas adjacentes, aumentando a variabilidade na população e a frequência de indivíduos resistentes ao longo do tempo (Wang et al., 2004).

Considerando os diferentes aspectos que determinam a resistência ou suscetibilidade de plantas de azevém, o presente trabalho objetivou avaliar características morfoanatômicas de folhas e raizes, adequar metodologia para a análise citológica de cromossomos e testar corantes para testes de viabilidade polínica de biótipos de azevém suscetivel e resistentes ao herbicida glyphosate.

\section{MATERIAL E MÉTODOS}

As sementes dos biótipos de azevém (Lolium multiflorum) suspeitos de resistência provieram de plantas que sobreviveram à aplicação de glyphosate em lavouras no município de São Valentin, RS (SVA 1 e SVA 4), e Passo Fundo, RS (PFU 5). As sementes do biótipo suscetivel (SVA 2) também foram obtidas em São Valentin, RS. Os biótipos foram escolhidos devido à proximidade geográfica e também aos menores sintomas de fitotoxicidade apresentados pelos biótipos resistentes.

Realizou-se a semeadura de quatro sementes por vaso, com capacidade volumétrica de $4 \mathrm{~L}$; posteriormente, quando as plantas apresentavam duas folhas, realizou-se desbaste, deixando-se uma planta por vaso. Quando as plantas apresentavam seis afilhos, foram separados quatro deles e replantados em substrato comercial Germina Plant ${ }^{\circledR}$. Dez dias 
após o replantio, plantas com 3-4 folhas foram submetidas a aplicação de $2.160 \mathrm{~g}$ e.a. ha $\mathrm{h}^{-1} \mathrm{de}$ glyphosate, produto comercial Glifosato Atanor $48^{\circledR}$. Para isso, utilizou-se pulverizador costal pressurizado a $\mathrm{CO}_{2}$, calibrado para proporcionar volume de aplicação de $120 \mathrm{~L} \mathrm{ha}^{-1}$ de calda herbicida, equipado com pontas de pulverização do tipo leque 110.015.

Para obtenção do material para os demais experimentos, as plantas-mãe, cujos afilhos sobreviveram, foram novamente repicadas e os afilhos transplantados para vasos com capacidade volumétrica de $8 \mathrm{~L}$, contendo solo tipo Argissolo Vermelho-Amarelo e substrato comercial Germina Plant ${ }^{\circledR}$ na proporção de 3:1. Adotou-se esse procedimento também para os afilhos das plantas do biótipo suscetível. A produção de afilhos nas plantas transplantadas foi induzida com a aplicação de adubação nitrogenada. Separaram-se os afilhos novamente e, então, organizaram-se os blocos do experimento conforme o estádio de desenvolvimento das plantas, exceto para a contagem cromossômica, que foi realizada a partir de sementes. A apresentação dos materiais e métodos específicos de cada experimento é feita a seguir.

\section{Caracterização morfoanatômica}

Para a caracterização morfológica, o experimento foi conduzido em delineamento experimental inteiramente casualizado com seis repetições. Quando atingiram o estádio de antese (floração), aproximadamente 100 dias após o transplante (DAT), as plantas foram identificadas quanto à espécie, com auxílio de chaves de identificação especializadas (Longhi-Wagner, 1987), examinadas com o auxílio de lupa e avaliadas quanto a suas características morfológicas (Tabela 1). Exsicatas de cada biótipo foram depositadas no

Tabela 1 - Características morfológicas de biótipos de azevém (Lolium multiflorum) suscetível (SVA 2) e resistente (SVA 1, SVA 4 e PFU 5) ao herbicida glyphosate

\begin{tabular}{|c|c|c|c|c|c|}
\hline \multirow{2}{*}{ Característica } & \multicolumn{4}{|c|}{ Biótipo } & \multirow{2}{*}{$\mathrm{CV}(\%)$} \\
\hline & SVA $2(\mathrm{~S})^{1^{1 /}}$ & SVA 1 (R) & SVA 4 (R) & PFU 5 (R) & \\
\hline Estatura da planta $(\mathrm{cm})$ & $55,7 \quad \mathrm{~b}^{-2 /}$ & 71,0 a & 74,8 a & 76,8 a & 11,40 \\
\hline Comprimento $(\mathrm{cm})$ da menor lâmina & $12,8 \quad b$ & 15,7 a & $10,8 \quad \mathrm{c}$ & $14,4 \mathrm{ab}$ & 8,83 \\
\hline Comprimento $(\mathrm{cm})$ da maior lâmina & $27,5 \quad b$ & $31,4 \mathrm{ab}$ & $30,8 \mathrm{ab}$ & $33,0 \quad \mathrm{a}$ & 12,83 \\
\hline Largura $(\mathrm{mm})$ da menor lâmina & $5,0 \quad b$ & 8,0 a & 7,0 a & $5,0 \quad \mathrm{~b}$ & 15,96 \\
\hline Largura $(\mathrm{mm})$ da maior lâmina & $9,0 \quad b$ & $10,0 \mathrm{ab}$ & 11,0 a & $12,0 \quad \mathrm{a}$ & 11,51 \\
\hline Comprimento (mm) da lígula & $1,3 \mathrm{a}$ & $0,8 \quad \mathrm{~b}$ & 1,3 a & $1,4 \quad \mathrm{a}$ & 21,38 \\
\hline Comprimento $(\mathrm{cm})$ da inflorescência & $25,2 \mathrm{~b}$ & 28,6 a & 30,6 a & 29,8 a & 6,72 \\
\hline Número de espiguetas por inflorescência & 33,6 a & $27,6 \quad b$ & $28,8 \quad \mathrm{~b}$ & $29,0 \quad \mathrm{~b}$ & 8,64 \\
\hline Comprimento (mm) da espigueta (sem arista) & $14,0 \quad \mathrm{~b}$ & 17,0 a & 17,0 a & $19,0 \quad \mathrm{a}$ & 8,62 \\
\hline Largura $(\mathrm{mm})$ da espigueta & $6,0 \quad \mathrm{~b}$ & $6,0 \quad \mathrm{~b}$ & $7,0 \quad \mathrm{a}$ & $5,0 \quad \mathrm{~b}$ & 8,99 \\
\hline Número de nervuras da gluma II & $5,7 \mathrm{~b}$ & $4,7 \mathrm{~b}$ & $7,0 \quad \mathrm{a}$ & $5,0 \quad b$ & 14,25 \\
\hline Comprimento (mm) da gluma II & $9,8 \mathrm{c}$ & $9,4 \mathrm{c}$ & $12,9 \mathrm{~b}$ & 15,4 a & 11,22 \\
\hline Largura $(\mathrm{mm})$ da gluma II & $1,0 \mathrm{c}$ & $1,6 \mathrm{~b}$ & $2,0 \quad \mathrm{a}$ & $1,5 \mathrm{~b}$ & 6,71 \\
\hline Número de nervuras da lema & $3,3 \mathrm{~b}$ & $3,8 \mathrm{ab}$ & 4,5 a & $3,8 \mathrm{ab}$ & 14,71 \\
\hline Comprimento $(\mathrm{mm})$ da lema $(\mathrm{com} \text { arista })^{3 /}$ & $5,5 \mathrm{~b}$ & $6,7 \quad \mathrm{a}$ & $6,5 \mathrm{a}$ & 6,9 a & 6,58 \\
\hline Largura $(\mathrm{mm})$ da lema & $1,4 \quad a b$ & $1,5 \mathrm{ab}$ & $1,7 \quad \mathrm{a}$ & $1,3 \mathrm{~b}$ & 18,25 \\
\hline Comprimento $(\mathrm{mm})$ da pálea ${ }^{3 /}$ & $5,3 \mathrm{~b}$ & $5,2 \mathrm{~b}$ & $6,5 \mathrm{a}$ & $6,7 \mathrm{a}$ & 6,54 \\
\hline Largura $(\mathrm{mm})$ da pálea & $1,5 \mathrm{ab}$ & $1,7 \mathrm{a}$ & $1,8 \quad \mathrm{a}$ & $1,3 \mathrm{~b}$ & 14,60 \\
\hline Comprimento $(\mathrm{mm})$ das anteras (indeiscentes) & $4,2 \mathrm{a}$ & $3,6 \mathrm{~b}$ & $4,1 \quad \mathrm{a}$ & 4,2 a & 7,28 \\
\hline $\mathrm{AF}\left(\mathrm{cm}^{2}\right)^{4 /}$ & $22,8 \quad \mathrm{~b}$ & 29,9 a & 34,2 a & 34,3 a & 9,57 \\
\hline
\end{tabular}

1/ Suscetível (S) e resistente (R). ${ }^{2 /}$ Médias seguidas pela mesma letra, na linha, não diferem significativamente pelo teste de Duncan $(\mathrm{p} \leq 0,05) .{ }^{3 /}$ Avaliado no primeiro antécio, da primeira espigueta da inflorescência. ${ }^{4 /} \mathrm{AF}=($ Comprimento $(\mathrm{cm})$ da maior lâmina $\mathrm{x}$ Largura (cm) da maior lâmina) 
herbário PEL da Universidade Federal de Pelotas (UFPel).

Analisaram-se os dados das características quantitativas quanto à normalidade (teste de Shapiro-Wilk), com posterior análise de variância $(p \leq 0,05)$. As médias dos biótipos foram comparadas pelo teste de Duncan $(\mathrm{p} \leq 0,05)$.

Para as análises anatômicas, realizou-se experimento em delineamento experimental inteiramente casualizado com cinco repetições. Amostras da quarta folha totalmente expandida, e de raízes, foram coletadas a partir de plantas em estádio de quatro folhas a um afilho, fixadas em solução de Karnovsky modificada, com a utilização de tampão fosfato $\mathrm{pH} 7,2$, desidratadas em série etílica ascendente e infiltradas em resina plástica (Leica Historesin ${ }^{\circledR}$ ), segundo as instruções do fabricante. As amostras foram seccionadas em micrótomo rotativo manual (ANCAP) com navalha descartável (Feather $\left.{ }^{\circledR}\right)$. As secções com $5 \mu \mathrm{m}$ de espessura foram coradas com azul de Toluidina 0,05\% (Sakai, 1973) em tampão

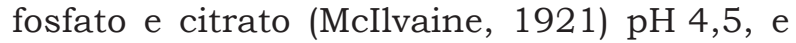
montadas em resina sintética "Entellan" (Merck $\left.{ }^{\circledR}\right)$.

A documentação dos resultados da análise histológica foi feita através da captura de imagens, a partir das lâminas, usando câmera Leica $^{\circledR}$ DC $300 \mathrm{~F}$ acoplada ao microscópio Leica ${ }^{\circledR}$ DM LB, na objetiva de 20X. Foram realizadas análises qualitativas das imagens obtidas, com posterior comparação entre os biótipos.

\section{Contagem cromossômica}

Para a análise citológica de cromossomos mitóticos, sementes de azevém foram colocadas para germinar, distribuídas uniformemente sobre duas folhas de papel germitest, umedecidas com $5 \mathrm{~mL}$ de água e mantidas em câmara de crescimento, a $25 \pm 1^{\circ} \mathrm{C}$, com fotoperíodo de $12 \mathrm{~h}$. Para análise dos meristemas em estádio que apresentasse maior número de células em divisão, facilitando assim a análise citológica, coletou-se a parte aérea das plântulas com $3 \mathrm{~cm}$ de comprimento e as raizes com: (a) $0,5 \mathrm{~cm}$, (b) $1 \mathrm{~cm}$, (c) $1,5 \mathrm{~cm}$ e (d) $3 \mathrm{~cm}$ de comprimento; a seguir, os tecidos foram fixados em álcool absoluto e ácido acético glacial 3:1 (fixador de Carnoy I), em temperatura ambiente, por duas horas, sendo posteriormente armazenados, em álcool $70 \%$, a $6 \pm 2{ }^{\circ} \mathrm{C}$, até a preparação das lâminas.

Após esse procedimento, estabeleceu-se o processo de amaciamento da parede celular (hidrólise) com $\mathrm{HCl} 5 \mathrm{~N}$, em temperatura ambiente por 5, 10, 15 e 20 min; posteriormente, testaram-se os corantes para lâminas temporárias orceína acética $2 \%$ e carmim acético $1 \%$, para visualização dos cromossomos.

Uma vez determinado o tamanho da ponta de raiz a ser utilizada, o tempo de hidrólise e o corante, testaram-se diferentes tempos de exposição ao agente antimitótico (8-hidroxiquinoleina - $8 \mathrm{HQ}$ ) em molaridade de $0,02 \mathrm{M}$, mantendo-se as raízes imersas nele por $2,5,14$ e 24 horas a $4{ }^{\circ} \mathrm{C}$.

Em todas as etapas do experimento, para o preparo das lâminas da contagem cromossômica, as pontas de raiz foram retiradas do fixador e lavadas três vezes em água destilada, por cerca de $30 \mathrm{~s}$, sendo submetidas ao processo de amaciamento da parede celular e, novamente, lavadas em água destilada. $\mathrm{Na}$ sequência, o meristema radicular foi retirado, com auxilio de agulhas histológicas e microscópio esteroscópico, sendo colocado sobre a lâmina e esmagado com uma gota de corante e bastão de vidro. Posteriormente, o material foi coberto com laminula e pressionado com lápis borracha. A lâmina foi aquecida sobre a chama de lamparina, e o material, prensado entre lâmina e lamínula com uma microprensa. A análise cromossômica foi feita em microscópio óptico, com objetiva de 40 e 100 x, utilizando-se o método de varredura, partindo do canto inferior direito da lâmina.

\section{Viabilidade polinica}

Coletaram-se, de forma aleatória, dez inflorescências de cada biótipo logo após a antese, transportando-as para o laboratório em placas de Petri fechadas. No laboratório, as inflorescências foram imersas em fixador Carnoy 3:1 (etanol: ácido acético) e mantidas em temperatura ambiente por duas horas. Depois, o material foi transferido para o álcool $70 \%$ e armazenado em temperatura de $6 \pm 2{ }^{\circ} \mathrm{C}$, até o preparo das lâminas. 
O material foi colocado sobre uma lâmina, retirando-se da inflorescência dez anteras, que eram seccionadas para a liberação dos grãos de pólen. Em seguida, era adicionada uma gota do corante a ser testado e cobria-se o material com lamínula; após $10 \mathrm{~min}$, prepararam-se as lâminas.

O delineamento experimental foi o inteiramente casualizado com quatro repetições. Contaram-se 100 grãos de pólen por lâmina em microscópio óptico com objetiva de aumento de $40 \mathrm{x}$, sendo cada lâmina considerada uma repetição. Os tratamentos foram arranjados em esquema fatorial cujo fator A testou os biótipos de azevém (SVA 1, SVA 2, SVA 4 e PFU 5); o fator B avaliou diferentes corantes (azul de tripan, azul de amã, orceína acética $2 \%$, carmim acético $1 \%$ e carmim propiônico $1 \%$ ); e o fator C constou de pólen fresco e fixado.

Consideraram-se viáveis os grãos de pólen que apresentaram a exina intacta, com protoplasma bem corado e com distribuição homogênea, e inviáveis aqueles que possuiam tamanho anormal, coloração fraca e/ou protoplasma reduzido ou ausente para a maioria dos corantes testados, exceto para o azul de tripan, cujos pólens viáveis não permitem a entrada do corante.

Os dados foram analisados quanto à normalidade (teste de Shapiro-Wilk), com posterior análise de variância $(p \leq 0,05)$. Quando foi observada significância estatística, as médias dos fatores biótipos, corantes e pólen fresco ou fixado foram comparadas pelo teste de Duncan $(\mathrm{p} \leq 0,05)$.

\section{RESULTADOS E DISCUSSÃO}

\section{Caracterização morfoanatômica}

O estudo da morfologia das plantas de azevém coletadas nas lavouras do RS revelou que todos os acessos (biótipos) analisados foram identificados como da espécie L. multiflorum, depositados em herbário sob os seguintes números: 25868=SVA 2: $25867=$ SVA 1, 25870=SVA 4: e 25871=PFU 5. As características morfológicas quantitativas analisadas para identificação dos exemplares estão listadas na Tabela 1 .
As plantas caracterizam-se por apresentar ciclo anual, com base violácea. Os colmos são eretos a decumbentes, glabros, com nós violáceos. Apresentam pré-foliação convoluta, lâminas verdes brilhantes, pilosas, com aurículas glabras, membranosas e amplexicaules e lígula truncado-membranosa. As inflorescências são do tipo espiga dística, ausência da gluma I nas espiguetas laterais e presença somente na espigueta terminal. A gluma II está presente em todas as espiguetas, com forma lanceolada e ápice agudo. A pálea possui ápice agudo, e as flores apresentam três estames. Todos os resultados morfológicos qualitativos e quantitativos corroboram os relatos de Boldrini et al. (2008).

Analisando a estatura das plantas, observou-se que os biótipos resistentes (R) SVA 1, SVA 4 e PFU 5 mostraram-se, em média, 25\% maiores em estatura que o biótipo suscetivel (S) SVA 2 (Tabela 1). Em trabalho realizado com azevém, o biótipo R ao glyphosate foi cerca de 10 e $20 \%$ superior em estatura ao S e outro R, respectivamente (Galvan, 2009). A estatura representa característica morfológica importante que interfere na competição por luz; espécies que possuem maior estatura e área foliar são favorecidas, interceptando mais radiação solar, aumentando a fotossintese.

Para o comprimento da menor lâmina, SVA 4 demonstrou redução próxima a 50\%, comparado a SVA 1 (Tabela 1). Já para a largura da menor lâmina, observou-se que não houve diferença entre esses biótipos, sendo eles superiores a SVA 2 e PFU 5. Avaliando o comprimento e largura da maior lâmina, verificou-se que o biótipo PFU 5 foi 15 e 25\% superior ao SVA 2, respectivamente para as duas variáveis. O biótipo SVA 1 possuía lígula $40 \%$ menor que a do PFU 5. Em biótipos de azevém resistente e suscetivel ao glyphosate não se verificou diferença significativa para as variáveis comprimento e largura da maior folha (Galvan, 2009).

O biótipo SVA 4 possuía inflorescências 20\% maiores em comprimento que as do SVA 2. Quanto à variável espiguetas por inflorescência, verifica-se que SVA 2 apresentou número cerca de $20 \%$ maior que o do SVA 1 (Tabela 1). Para o comprimento da espigueta, SVA 2 apresentu redução de $25 \%$ quando 
comparado ao PFU 5, ao passo que, para a largura dela, SVA 4 mostrou-se cerca de 30\% superior a PFU 5. Segundo Galvan (2009), as variáveis comprimento da inflorescência, número de espiguetas por inflorescência e comprimento da espigueta basal não apresentaram diferença significativa entre os biótipos de azevém suscetível e resistente ao glyphosate.

Analisando a gluma II, observou-se que SVA 1 apresenta redução de 30\% no número de nervuras, comparativamente a SVA 4 (Tabela 1). O biótipo PFU 5 mostrou comprimento $40 \%$ superior da gluma II, quando comparado ao SVA 1. A largura da gluma II foi $50 \%$ maior em SVA 4, em comparação com o biótipo S SVA 2. O comprimento e a largura da gluma não apresentaram diferença entre os biótipos de azevém suscetivel e resistente ao glyphosate (Galvan, 2009).

Quanto à lema, verificou-se que o número de nervuras do biótipo SVA 4 foi $25 \%$ superior ao do SVA 2. O comprimento da lema do PFU 5 foi $20 \%$ maior, comparado ao SVA 2, e a largura da lema do PFU 5 foi cerca de 20\% menor que a do SVA 4 (Tabela 1). Para a variável comprimento da pálea, o biótipo PFU 5 mostrou-se 20\% superior ao biótipo SVA 1. A largura da pálea foi 30\% menor no biótipo PFU 5, quando comparado ao SVA 4. Quanto às anteras, verificou-se que SVA 2 apresentou comprimento 15\% maior que o biótipo SVA 1 (Tabela 1). Os biótipos R SVA 4 e PFU 5 mostraram comportamento similar para a variável área foliar, com valores próximos a $34 \mathrm{~cm}^{2}$, sendo estes cerca de 30\% superiores aos do biótipo S SVA 2. Características morfológicas, como capacidade de afilhamento, estatura de planta, área foliar, distribuição das folhas, ângulo foliar e produção de massa aérea, influenciam na interceptação de luminosidade pelo dossel foliar.

Os biótipos de azevém que apresentam resistência ao herbicida glyphosate não podem ser diferenciados do biótipo S através de aspectos morfológicos, pois pertencem à mesma espécie. Contudo, entre os biótipos resistentes, o biótipo SVA 4 apresentou-se superior em praticamente todas as variáveis quantitativas analisadas, o que lhe permite ser mais competitivo, necessitando, dessa forma, de especial atenção quanto ao seu controle nas fases iniciais de desenvolvimento, evitando que ele atinja a fase reprodutiva.

As análises anatômicas mostraram que o mesofilo de azevém é homogêneo, constituído de células parenquimáticas compactamente distribuídas, e os feixes vasculares são envoltos pela bainha do feixe (Figura 1A-D). Observouse que o biótipo S SVA 2 apresentou poucos espaços intercelulares e reduzido tamanho das células da bainha, comparado ao PFU 5 (Figura 1A e D). A avaliação de biótipo de L. multiflorum resistente ao herbicida glyphosate mostrou células do mesofilo menos compactadas, bem como menor proporção de floema em relação ao xilema, características insuficientes para confirmar a menor absorção e translocação do glyphosate (Galvan, 2009). A maior compactação das células do mesofilo torna a quantidade de $\mathrm{CO}_{2}$ circulante menor para ser utilizada na fotossíntese.

A existência de gases no mesofilo exerce maior pressão no interior da lâmina foliar, dificultando a passagem da água e, consequentemente, do glyphosate translocado, tanto pela via apoplasto como pelo simplasto (Galvan, 2009). O mesofilo de Brassica juncea tolerante ao glyphosate apresentou menos espaços livres entre as células quando comparado à população suscetível, sendo considerada uma das causas da tolerância, pela redução da absorção foliar do herbicida (Huangfu et al., 2009). Assim, a maior quantidade de espaços intercelulares no mesofilo pode colaborar para a menor sensibilidade dos biótipos resistentes ao herbicida.

As características da superficie foliar, bem como do mesofilo e tecidos vasculares, podem afetar a eficácia da absorção do glyphosate em plantas daninhas, pela sua influência na adesão e absorção do herbicida na folha (Huangfu et al., 2009). Características da superficie da folha, como cutícula (cera epicuticular, cutina e pectina), ângulo e posição da folha, número de estômatos, tricomas e glândulas, interferem na absorção foliar de herbicidas (Huangfu et al., 2009).

O glyphosate se movimenta no floema seguindo a rota dos produtos da fotossintese, das folhas fotossinteticamente ativas, em direção às partes das plantas em crescimento. 

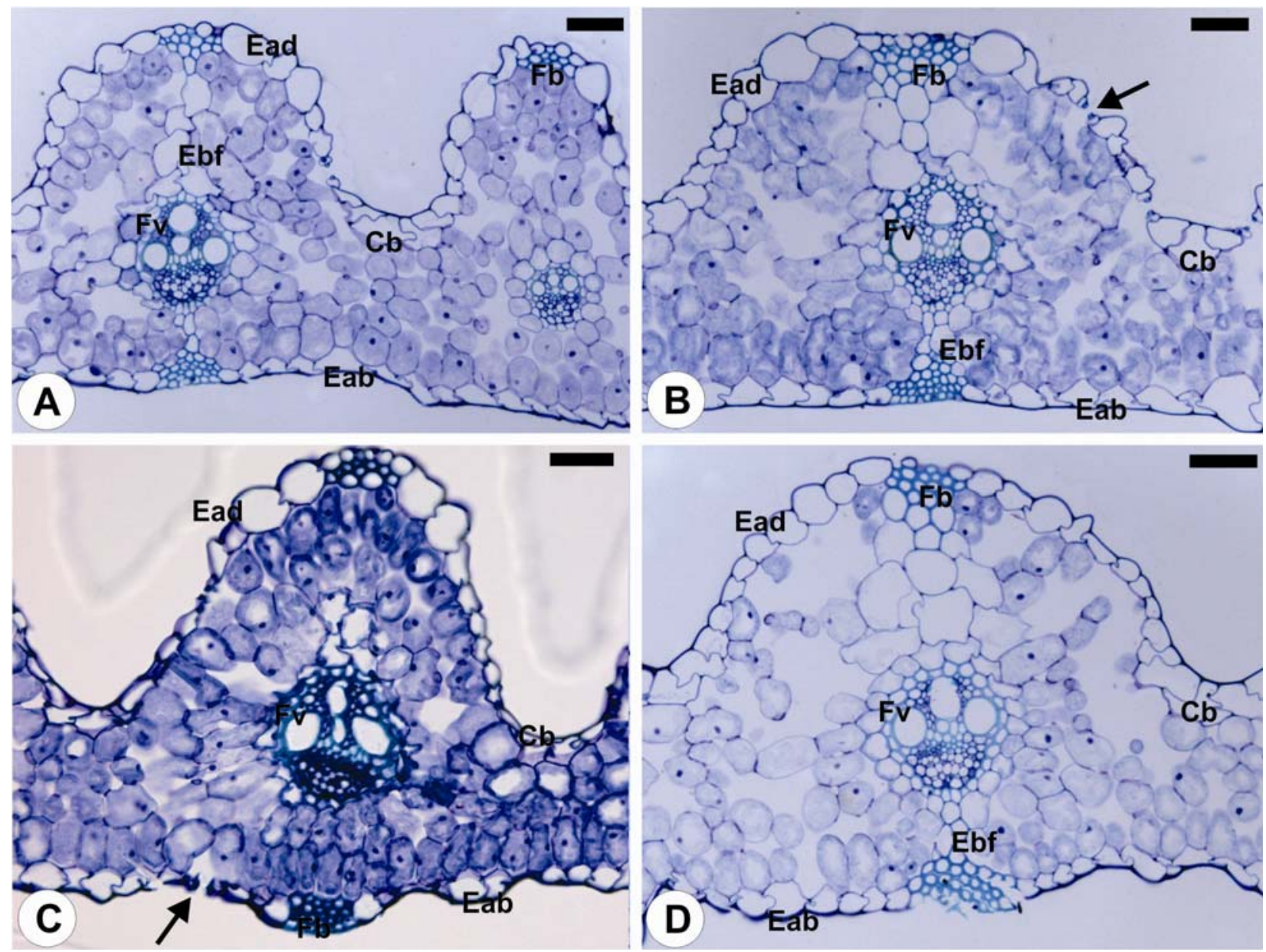

Setas = indicam os estômatos. $\mathrm{Cb}=$ células buliformes; Eab = epiderme da face abaxial (inferior); Ead = epiderme da face adaxial (superior); $\mathrm{Ebf}=$ extensões da bainha do feixe; Fv = feixe vascular (compreende o xilema - células maiores; e floema - células menores). Barras: A, B, $\mathrm{C}, \mathrm{D}=50 \mu \mathrm{m}$.

Figura 1 - Cortes transversais da folha dos biótipos de azevém (Lolium multiflorum) suscetível (SVA 2 (A)) e resistente (SVA 1 (B), SVA 4 (C) e PFU 5 (D)) ao herbicida glyphosate.

Populações tolerantes de Brassica juncea ao glyphosate apresentaram maior espessura da folha e da cutícula adaxial e maior densidade de tricomas na epiderme superior, bem como menor número de feixes vasculares, em comparação com as plantas suscetiveis, sugerindo que essas diferenças podem contribuir para a tolerância ao herbicida glyphosate (Huangfu et al., 2009).

Importante evidenciar que não houve diferença de absorção de glyphosate entre biótipos de azevém resistente e sucetível em trabalho conduzido por Ferreira et al. (2006), mas foi evidenciada maior retenção do herbicida nas folhas em biótipos $\mathrm{R}$, ao passo que, nos biótipos $\mathrm{S}$, grande parte do herbicida aplicado na parte aérea foi translocada para as raizes. Nesse contexto, torna-se importante a caracterização do sistema radical do azevém, a fim de avaliar os custos que possam surgir advindos da resistência.

As análises mostram acentuada lise das células do parênquima cortical e desorganização da epiderme e exoderme no biótipo $\mathrm{S}$ SVA 2, quando comparado aos biótipos R SVA 1 e PFU 5 (Figura 2A, B e D, respectivamente). No biótipo SVA 1 observou-se maior espessamento da endoderme, e as células do cilindro vascular apresentaram-se com paredes mais espessas e lignificadas que nos demais biótipos 

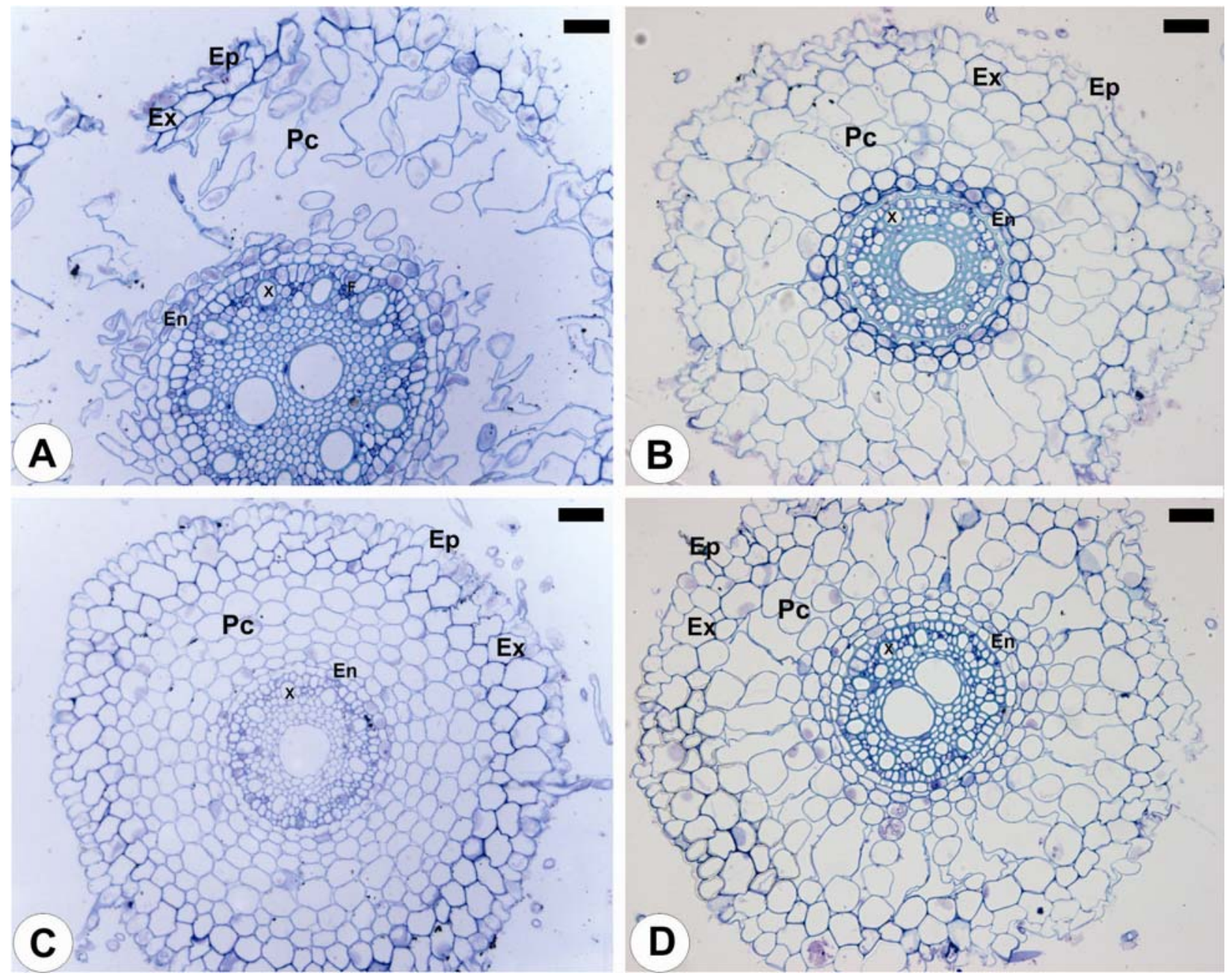

$\mathrm{En}=$ endoderme $; \mathrm{Ep}=$ epiderme; $\mathrm{Ex}=$ exoderme; $\mathrm{F}=$ floema; $\mathrm{Pc}=$ parênquima cortical; $\mathrm{X}=$ xilema. Barras: $\mathrm{A}, \mathrm{B}, \mathrm{C}, \mathrm{D}=50 \mu \mathrm{m}$.

Figura 2 - Cortes transversais da raiz dos biótipos de azevém (Lolium multiflorum) suscetível (SVA 2 (A)) e resistente (SVA 1 (B), SVA 4 (C) e PFU 5 (D)) ao herbicida glyphosate.

(Figura 2B). O biótipo SVA 4 não apresentou formação de espaços intercelulares conspícuos e espessamentos das paredes celulares das células que compõem o cilindro vascular (Figura 2C). Cabe ressaltar que o herbicida glyphosate não é absorvido pelas raízes, e sim pela parte aérea, e translocado via floema (Velini et al., 2009), ou seja, as modificações verificadas no sistema radicular não interferem diretamente na resistência dos biótipos ao herbicida.

Dessa maneira, a avaliação anatômica foliar e de raízes pode ser aplicada com sucesso na identificação de espécies suscetíveis, tolerantes ou resistentes a determinado produto químico, assim como na descrição dos sintomas fitotóxicos, contribuindo com os estudos de seletividade de herbicidas.

\section{Contagem cromossômica}

Os resultados dos diferentes protocolos testados evidenciam que o protocolo básico utilizado neste trabalho, que apresentou os melhores resultados na obtenção de cromossomos de Lolium multiflorum, foi o seguinte: (1) seleção das sementes viáveis; (2) germinação das sementes a $25^{\circ} \mathrm{C}$, com 12 horas de luz, por dois a sete dias; (3) coleta das pontas do 
meristema apical radicular nítido (desprovido de raízes secundárias) com $1,5 \mathrm{~cm}$ de comprimento ou da parte aérea; (4) prétratamento em 8 -HQ $0,002 \mathrm{M}$ por 24 horas, a $4 \pm 1{ }^{\circ} \mathrm{C}$; (5) fixar o material em álcool absoluto e ácido acético glacial 3:1 (fixador de Carnoy I), à temperatura ambiente; (6) armazenar em álcool $70 \%$, a $4-6{ }^{\circ} \mathrm{C}$, até a preparação das lâminas; (7) lavar as pontas de raiz ou parte aérea em água destilada, três vezes; (8) hidrolisar em $\mathrm{HCl} 5 \mathrm{~N}$ por $20 \mathrm{~min}$, em temperatura ambiente; (9) lavar o material em água destilada, três vezes; (10) retirar e esmagar o material vegetal com uma gota de corante orceína acética $2 \%$; (11) cobrir o material com lamínula e pressionar com lápis borracha; (12) aquecer, brevemente, a lâmina sobre a chama de lamparina; (13) prensar o preparado utilizando uma microprensa; e (14) analisar em microscópio.

Quanto à análise cromossômica mitótica, a maior quantidade de células em divisão mitótica é encontrada no tecido meristemático (Guerra \& Souza, 2002). Esse tecido pode ser encontrado em diferentes órgãos das plantas e caracteriza-se por não apresentar células diferenciadas. Para a análise citogenética deste trabalho, o comprimento ideal de raiz testado para as análises foi o de $1,5 \mathrm{~cm}$, pois as células possuem maior volume celular e têm crescimento rápido. Além disso, as pontas das raizes absorvem mais facilmente as soluções onde são mergulhadas, o que é importante no uso de antimitóticos e fixadores.

Os agentes antimitóticos agem em células de tecidos meristemáticos em divisão, inibindo, durante a metáfase, a formação do fuso mitótico e, consequentemente, o espalhamento dos cromossomos, além de provocar a contração uniforme dos braços cromossômicos (Singh, 2000). O tempo ideal de tratamento com esses produtos pode variar com a espécie, dependendo, principalmente, da temperatura e da concentração utilizadas (Guerra \& Souza, 2002). Ainda, as substâncias antimitóticas provocam sincronização celular e aumentam o número de metáfases, o que permite melhor visualização dos cromossomos e possibilita melhor visualização das constrições primárias e secundárias e, consequentemente, melhor definição da morfologia cromossômica, aumentando a viscosidade do citoplasma e facilitando a rápida penetração dos fixadores, pela remoção de depósitos indesejáveis nos tecidos (Singh, 2000).

Existe grande variabilidade entre populações selvagens e cultivadas de azevém, havendo ampla diversidade genética, o que cria cenário privilegiado para o melhoramento vegetal. A espécie L. multiflorum se apresentou naturalmente na forma diploide, com $2 \mathrm{n}=2 \mathrm{x}=14$ cromossomos (Pereira et al., 2012); no entanto, cultivares tetraploides, com $2 n=4 x=28$ cromossomos, foram originados pelo melhoramento genético vegetal, através da técnica de duplicação cromossômica (Oliveira, 2013).

O cruzamento entre indivíduos diploides (2n) e tetraploides (4n) surge espontaneamente e resulta em individuos triploides (3n) viáveis, mas caracteristicamente estéreis devido à presença de cromossomos não pareados na meiose. O conhecimento do nível de ploidia e do modo de reprodução das espécies é informação importante para determinar as estratégias de cruzamentos e condução de programas de melhoramento. Ainda, o nível de ploidia dos genótipos afeta a resposta das plantas daninhas aos herbicidas. Há relatos de que o azevém diploide apresenta suscetibilidade diferencial ao herbicida glyphosate, porém o tetraploide se mostra mais tolerante, fato que pode explicar o controle insatisfatório da planta daninha nas áreas de cultivo. Entretanto, o estádio fenológico de desenvolvimento das plantas pode afetar o grau de tolerância ao glyphosate em ambos os genótipos (Dors et al., 2010).

Dessa forma, os resultados obtidos poderão servir como base para outros trabalhos que envolvem o gênero Lolium, podendo-se associar informações tanto morfológicas, citogenéticas, quanto moleculares, chegando ao entendimento de quais espécies estão presentes no Brasil, sobretudo em áreas agrícolas competindo com as culturas, bem como quais espécies são nativas, introduzidas ou selecionadas pelo uso de herbicidas.

\section{Viabilidade polinica}

Verificou-se interação entre os fatores biótipos e corantes utilizados (Tabela 2). Para o 
fator pólen fresco e/ou fixado, não se observou significância. A comparação entre biótipos demonstrou que o corante azul de tripan apresentou menor viabilidade do pólen, independentemente de este ser fresco ou fixado (Tabela 2). Já na comparação entre biótipos, verificou-se que para o SVA 2 os corantes carmim propiônico e carmim acético foram os mais eficientes para avaliar a viabilidade do pólen fresco ou fixado, respectivamente. Para os biótipos SVA 1 e SVA 4, o carmim acético apresentou resultado mais pronunciado, independentemente de o pólen ser fresco ou fixado. Por sua vez, para o biótipo PFU 5, a orceína acética e o carmim propiônico foram os que indicaram maior viabilidade para pólen fresco e fixado, respectivamente.

O cultivar Waseaoba de azevém anual apresentou $98,6 \%$ de viabilidade polínica em casa de vegetação e $96 \%$ em campo utilizandose carmim acético (Kiyoshi et al., 2012). Em trabalho que avaliou dez genótipos de Lolium multiflorum, utilizando o corante carmim propiônico, verificou-se alta taxa de viabilidade polínica, maior que 89\% (Nunes et al., 2012). Já na avaliação da viabilidade dos grãos de pólen de Eragrostis plana pelo método de coloração com orceína acética, observou-se que todos os indivíduos analisados apresentaram 100\% de viabilidade (Piccinini et al., 2012).

Há vários métodos de determinação da viabilidade polínica, entre os quais está a coloração citoquímica, utilizando-se corantes. O uso de corantes é o método mais rápido, fácil e barato para verificar a viabilidade de pólen, porém esse método pode superestimar a viabilidade, pois, muitas vezes, grãos de pólen inviáveis podem ainda corar, por possuírem quantidade suficiente de enzimas, amido ou outras substâncias.

A avaliação comparativa da viabilidade polínica é procedimento recomendado na tentativa de obter resultados mais confiáveis. Vale ainda lembrar que a escolha da técnica depende da espécie a ser avaliada. Considerando-se que a manifestação do genótipo de um indivíduo é o resultado da contribuição dos gametas masculino e feminino, quanto maior a viabilidade polínica, maior a possibilidade da formação de diferentes combinações entre alelos, isto é, aumento da variabilidade (Souza et al., 2002). Assim, gramineas polinizadas pelo vento têm elevado potencial de passar seus genes a plantas adjacentes, aumentando a variabilidade (Wang et al., 2004).

Tabela 2 - Viabilidade (\%) do pólen fresco e fixado de biótipos de azevém (Lolium multiflorum) suscetível (SVA 2) e resistentes (SVA 1, SVA 4 e PFU 5) ao herbicida glyphosate, em função de diferentes corantes

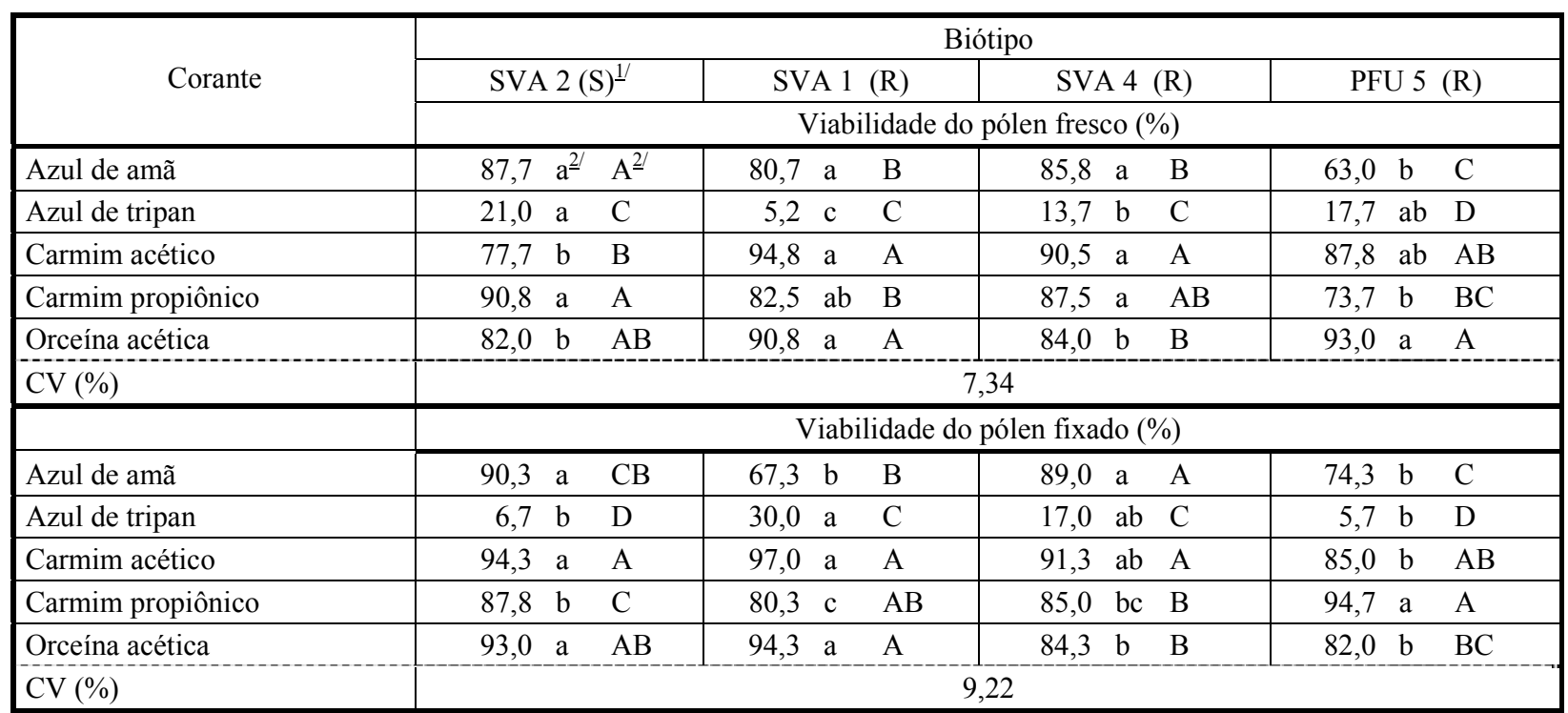

${ }^{1 /}$ Suscetível (S) e resistente (R). ${ }^{2 /}$ Médias seguidas pela mesma letra, minúscula nas linhas e maiúscula nas colunas, dentro de cada variável, não diferem significativamente pelo teste de Duncan $(p \leq 0,05)$. 
Como observado, todos os biótipos de azevém apresentaram alta estimativa de viabilidade polínica, porém esta pode ser perdida em função do tempo após a abertura da flor. Quando houver a sincronização da floração dos biótipos resistentes e suscetíveis, há possibilidade de cruzamento e recombinação gênica.

O azevém é uma espécie de polinização cruzada (alógama), resistente a vários herbicidas, entre eles o glyphosate. A herança dessa resistência é do tipo nuclear, com disseminação rápida na população, via pólen (Vargas et al., 2007). Dessa forma, o estudo do fluxo gênico mediado por pólen nessa espécie torna-se extremamente importante, pois a frequência de indivíduos resistentes em uma população pode aumentar consideravelmente ao longo do tempo.

Por fim, os resultados do trabalho mostram que os biótipos de azevém que apresentam resistência ao herbicida glyphosate não podem ser diferidos do biótipo suscetivel através de aspectos morfológicos, não existindo diferenças anatômicas de folha e raiz que evidenciem possibilidade de absorção diferencial do herbicida glyphosate entre os biótipos de azevém. A metodologia para a análise citológica dos biótipos de azevém merece algumas adequações para melhor nitidez dos cromossomos, podendo-se aumentar o tempo de hidrólise e de exposição ao agente antimitótico utilizado, bem como testar outros agentes. Com exceção do corante azul de tripan, todos os outros testados mostraram bom desempenho na determinação da viabilidade polínica frente aos biótipos avaliados.

\section{AGRADECIMENTOS}

À FAPERGS e CNPq, pelo apoio financeiro - Edital REPENSA; e à FAPERGS e CAPES, pela concessão de bolsas de Pós-Doutorado - Edital DOCFIX.

\section{LITERATURA CITADA}

BOLDRINI, I. I. et al. Morfologia e taxonomia de gramíneas sul-rio-grandenses. 2.ed. Porto Alegre: UFRGS, 2008. 87 p.

DALL'ARMELLINA, A. A.; ZIMDAHL, R. L. Effect of watering frequency, drought, and glyphosate on growth of field bindweed (Convolvulus arvensis). Weed Sci., v. 37, n. 3, p. 314-318, 1989.
DORS, C. A. et al. Suscetibilidade de genótipos de Lolium multiflorum ao herbicida glyphosate. Planta Daninha, v. 28, n. 2, p. 401-410, 2010.

FERREIRA, E. A. et al. Translocação do glyphosate em biótipos de azevém (Lolium multiflorum). Planta Daninha, v. 24, n. 2, p. 365-370, 2006.

GALVAN, J. Aspectos morfofisiológicos e anatômicos do azevém e controle de biótipos resistentes ao glifosato. 2009. 110 f. Dissertação (Mestrado em Agronomia) Faculdade de Agronomia e Medicina Veterinária, Universidade de Passo Fundo, Passo Fundo, 2009.

GUERRA, M.; SOUZA, M. J. Como analisar cromossomos: um guia de técnicas em citogenética vegetal, animal e humana. Ribeirão Preto: Funcep, 2002. 131 p.

HUANGFU, C. H. et al. ISSR variation within and among wild Brassica juncea populations: implication for herbicide resistance evolution. Genet. Res. Crop Evol., v. 56, n. 7, p. 913-924, 2009.

KIYOSHI, T. et al. Exceptionally high fertility observed in three F1 hybrids between Lolium multiflorum Lam. and L. temulentum L. J. Jpn. Grassl. Sci., v. 58, n. 2, p. 66-72, 2012.

LONGHI-WAGNER, H. M. Gramineae: tribo Poeae. Porto Alegre: Universidade Federal do Rio Grande do Sul, 1987. 191 p. (Boletim do Instituto de Biociências, 41)

MAXWELL, B. D.; MORTIMER, A. M. Selection for herbicide resistance. In: Herbicide resistance in plants: biology and biochemistry. Boca Raton: Lewis Publishers, 1994. p. 1-25.

MCILVAINE, T. C. A buffer solution for colorimetric comparison. J. Biol. Chem., v. 49, n. 1, p. 183-186, 1921.

NUNES, R. C. et al. Morphology and pollen viability of Lolium multiflorum Lam. Ci. Agrotec., v. 36, n. 2, p. 180-188, 2012.

OLIVEIRA, L. V. Características morfogênicas e estruturais de azevém. 2013. 65 f. Dissertação (Mestrado em Zootecnia) - Faculdade de Agronomia Eliseu Maciel, Universidade Federal de Pelotas, Pelotas, 2013.

PEREIRA, R. C. at al. Duplicação cromossômica de gramíneas forrageiras: uma alternativa para programas de melhoramento genético. Ci. Rural, v. 42, n. 7, p. 1278-1285, 2012.

PICCININI, F. et al. Pollen viability of Eragrostis plana genotypes from different geographic populations in Rio Grande do Sul. Enc. Biosfera, v. 8, n. 15, p. 1316-1324, 2012.

Planta Daninha, Viçosa-MG, v. 33, n. 3, p. 567-578, 2015 
SINGH, N. P. A simple method for accurate estimation of apoptotic cells. Exp. Cell Res., v. 256, n. 1, p. 328-337, 2000.

SAKAI, W. S. Simple method for differential staining of paraffin embedded plant material using toluidine blue $\mathrm{O}$. Stain Technol., v. 48, n. 5, p. 247-249, 1973.

SOUZA, M. M. et al. Microsporogênese e microgametogênese associadas ao tamanho do botão floral e da antera, e viabilidade polínica em maracujá amarelo (Passiflora edulis f. flavicarpa Degener). Ci. Agrotec., v. 26, n. 6, p. 1209-1217, 2002.

TUFFI SANTOS, L. D. et al. Efeito do glyphosate sobre a morfoanatomia das folhas e do caule de Commelina diffusa e C. benghalensis. Planta Daninha, v. 22, n. 1, p. 101-108, 2004.
VARGAS, L. et al. Herança da resistência de azevém (Lolium multiflorum) ao glyphosate. Planta Daninha, v. 25, n. 3, p. 567-571, 2007.

VARGAS, L. et al. Resistência de plantas daninhas a herbicidas. Viçosa, MG: Jard Produções, 1999. 131 p.

VELINI, E. D. et al. Glyphosate. Botucatu: FEPAF, 2009. $496 \mathrm{p}$.

WANG, Z. et al. Viability and longevity of pollen from transgenic and nontransgenic tall fescue (Festuca arundinacea) (Poaceae) plants. Am. J. Bot., v. 91, n. 4, p. 523-530, 2004.

WESTWOOD, J. H. et al. Absorption and translocation of glyphosate in tolerant and susceptible biotypes of field bindweed (Convolvulus arvensis). Weed Sci., v. 45, n. 5, p. 658-663, 1997. 